\title{
Produksi Tepung Kepiting dari Hasil Samping Usaha Budidaya Kepiting Soka
}

\author{
[Production of Crab Flour from By-Product of Soka Crab Cultivation]
}

Teuku Muamar Indra Akbarsyah ${ }^{1,2}$, Aef Permadi ${ }^{1}$

${ }^{1}$ Politeknik Ahli Usaha Perikanan Jakarta, Jl. Aup Bar. Jl. Raya Pasar Minggu, RT.1/RW.9, Jati

Padang, Kec. Ps. Minggu, Kota Jakarta Selatan, Daerah Khusus Ibukota Jakarta 12520

2Sekolah Usaha Perikanan Menengah Negeri (SUPM) Ladong, Jl. Laksamana Malahayati km.27, Desa Ladong, Kecamatan Mesjid Raya, Kabupaten Aceh Besar, Provinsi Aceh 23381

\begin{abstract}
Abstrak
Latar belakang penelitian ini adalah terdapatnya potensi pemanfaatan hasil samping dari budidaya kepiting soka untuk dijadikan produk bernilai tambah yang bermanfaat berupa tepung kepiting. Tujuan dari penelitian ini adalah untuk mengidentifikasi produksi tepung kepiting dari hasil samping budidaya kepiting soka berupa limbah kaki jalan. Metode yang digunakan adalah wawancara, observasi langsung, perlakuan uji coba produksi tepung kepiting dan uji sensori menggunakan scoresheet terhadap produk kepiting. Hasil yang diperoleh adalah rata rata bibit yang dibudidayakan adalah 1,5 ton/bulan yang menghasilkan limbah kaki jalan 9,55\%. Proses pemotongan kaki jalan merupakan rutinitas yang dilakukan oleh pembudidaya kepiting soka untuk mempercepat proses moulting atau panen. Produksi tepung kepiting berlangsung selama 1 hari yang menghasilkan rendemen produk sebesar $27,23 \%$ dan mempunyai kualitas mutu sensori grade A dengan nilai 8,05. Nilai terendah uji sensori terdapat pada parameter penampakan sedangkan nilai tertinggi uji sensori terdapat pada parameter benda asing. Kesimpulan penelitian ini adalah terdapat potensi pemanfaatan limbah kaki jalan sebesar $143,25 \mathrm{~kg} / \mathrm{bulan}$ yang bisa dijadikan tepung ikan sebesar $39 \mathrm{~kg} / \mathrm{bulan}$ yang berkualitas yang bisa dimanfaatkan oleh pembudidaya kepiting soka.
\end{abstract}

Kata kunci : hasil samping; limbah kaki jalan; rendemen; tepung kepiting

\section{Abstract}

The background of this research is the potential for the utilization of the by-product of soft shell crab culture to be used as a useful added value product in the form of crab flour. The purpose of this study was to identify the production of crab flour from the by-product of soft shell crab cultivation in the form of walk legs waste. The methods used were interviews, direct observation, testing of crab flour production and sensory testing using a scoresheet for crab products. The results obtained were that the average seedlings cultivated were 1.5 tonnes/month which resulted in $9.55 \%$ of pereiopod waste. The process of cutting the legs of the walk is a routine carried out by Soka crab cultivators to speed up the moulting or harvesting process. The production of crab flour lasts for 1 day which results in a product yield of $27.23 \%$ and has a grade A sensory quality with a value of 8.05. The lowest value of the sensory test is in the appearance parameter, while the highest value of the sensory test is in the foreign object parameter. The conclusion of this research is that there is a potential for the utilization of walking leg waste of 143.25 $\mathrm{kg} /$ month which can be used as high quality fish meal for $39 \mathrm{~kg} / \mathrm{month}$ which can be utilized by soft-shell crab cultivators.

Keywords : by-product, pereiopod waste; yield; crab flour 


\section{Penulis Korespondensi}

Teuku Muamar Indra Akbarsyah | amar.thefisher@gmail.com

\section{PENDAHULUAN}

Kepiting soka (Scylla serrata) adalah kepiting bakau yang mengalami fase ganti kulit (moulting) sehingga mempunyai cangkang yang lunak (soft shell crabs) dan dapat dimakan seutuhnya (Harianto E., 2015). Kepiting ini harganya lebih mahal dibandingkan dengan kepiting biasa yang bercangkang keras. Kepiting soka dibudidayakan oleh masyarakat pesisir. Teknik untuk mendapatkan kepiting lunak yang lebih mudah terkontrol jumlahnya dapat dilakukan dengan metode mutilasi dan ablasi (Khairiah et al., 2012). Teknik budidaya kepiting soka tersebut menghasilkan hasil samping berupa cangkang hasil dari moulting dan kaki jalan hasil mutilasi yang belum dimanfaatkan (Arthatiani et al., 2014).

Hasil identifikasi potensi ekonomi pemanfaatan limbah cangkang kepiting soka, dapat menjadikan mata pencaharian alternatif sehingga dapat meningkatkan pendapatan.

Pemanfaatan limbah kepiting soka lainnya adalah untuk usaha tepung ikan, pembuatan pakan ikan dan unggas, olahan makanan ringan tulang ikan, kerajinan aksesoris berupa tas atau dompet dan pembuatan tepung bahan baku kitosan (Luhur \& Zulham, 2016). Tepung dari hasil samping budidaya kepiting bisa dimanfaatkan sebagai bahan baku kitosan, perisa atau sebagai pakan ternak (Sari \& Abdiani, 2015). Pemanfaatan cangkang kepiting untuk bioteknologi antara lain sebagai biokatalis pada industri minyak palm (Boey et al., 2009) dan bioabsorban (A.Z et al., 2014).

Komposisi kimia pada tepung cangkang kepiting menunjukkan bahwa produk ini cocok untuk diolah lebih lanjut karena memiliki kalsium 14,06\%, kadar air 4,49\%, kadar abu $74 \%$, lemak $0,17 \%$, protein $10 \%$ dan karbohidrat 11,34\% (Handayani et al., 2019). Tepung cangkang kepiting yang belum melalui perlakuan panas dengan suhu tinggi, kaya akan mineral seperti karbon $(\mathrm{C})$ $19,78 \%$, komponen oksida $24,53 \%$, magnesium $(\mathrm{MgO})$ 4,81\%, $\mathrm{P}_{2} \mathrm{O}_{5}$ sebanyak 3,98\% dan $\mathrm{Ca}$ ) sebanyak $71,42 \%$ (Haryati et al., 2019).

Berbagai jenis metode dapat dilakukan untuk memproduksi tepung kepiting, tergantung pada tujuan pemanfaatan tepung kepiting. Pemanasan pada suhu tinggi $900^{\circ} \mathrm{C}$ 
selama 2 jam pada pembuatan tepung kepiting bertujuan untuk melakukan kalsinasi tepung yang dihasilkan (Fajri et al., 2019). Pembuatan tepung dari cangkang kepiting dengan cara pengeringan cangkang menggunakan sinar matahari selama 8 jam, kemudian dihaluskan hingga 60 mesh, pemanfaatan sebagai sumber kalsium pada pakan (Hamka et al.,2020). Pembuatan tepung cangkang kepiting yang mudah dan ramah lingkungan diperlukan untuk para pembudidaya tanpa mengurangi mutu tepung yang dihasilkan.

Tujuan dari penelitian ini adalah untuk mengidentifikasi potensi tepung kepiting dari hasil samping budidaya kepiting soka berupa limbah kaki jalan

\section{BAHAN DAN METODE}

Penelitian ini dilakukan di Kota Banda Aceh selama 1 bulan pada tanggal 4 Januari hingga 4 Februari 2021. Responden yang digunakan pada penelitian ini adalah tiga Usaha Kecil Menengah (UKM) pembudidaya kepiting soka, yaitu UKM Pak Zulfan, UKM Pak Ismiadi dan UKM Pak Martunus. Bahan yang digunakan adalah hasil samping budidaya kepiting soka berupa limbah kaki jalan hasil mutilasi sebagai bahan baku tepung kepiting, air bersih dan plastik kemasan berbahan gabungan antara LDPE, PET, dan NYLON (plastik vacuum)

Alat yang digunakan pada penelitian ini adalah timbangan digital (Camry), panci presto, spinner, para para, dan sealer elektrik.

Metode yang digunakan dalam penelitian ini adalah wawancara kepada pembudidaya kepiting soka untuk mendapatkan data sekunder, dilanjutkan dengan observasi langsung yang dimulai dari mengikuti proses pemotongan kaki jalan kepiting, dan perhitungan terhadap rendemen limbah kaki jalan. Selanjutnya dilakukan percobaan produksi tepung kepiting dengan pendekatan produksi tepung rajungan (Yanuar, 2013). Proses produksi dimodifikasi tanpa mengubah prinsip dalam pembuatan tepung rajungan untuk menyesuaikan karakteristik bahan baku dan ketersediaan alat. Tepung kepiting yang diperoleh dinilai mutu sensorinya menggunakan scoresheet uji organoleptik pada SNI 2715:2013. Sebanyak 10 panelis digunakan untuk menguji sensori tepung kepiting.

Kemudian tepung kepiting ditimbang untuk mengetahui jumlah rendemen yang didapat. Data yang diperoleh dianalisis secara deskripsi. Analisis statistik sederhana untuk menampilkan data menggunakan software excel dari microsoft 2010. 
Alur proses pengolahan tepung kepiting disajikan pada Gambar 1.
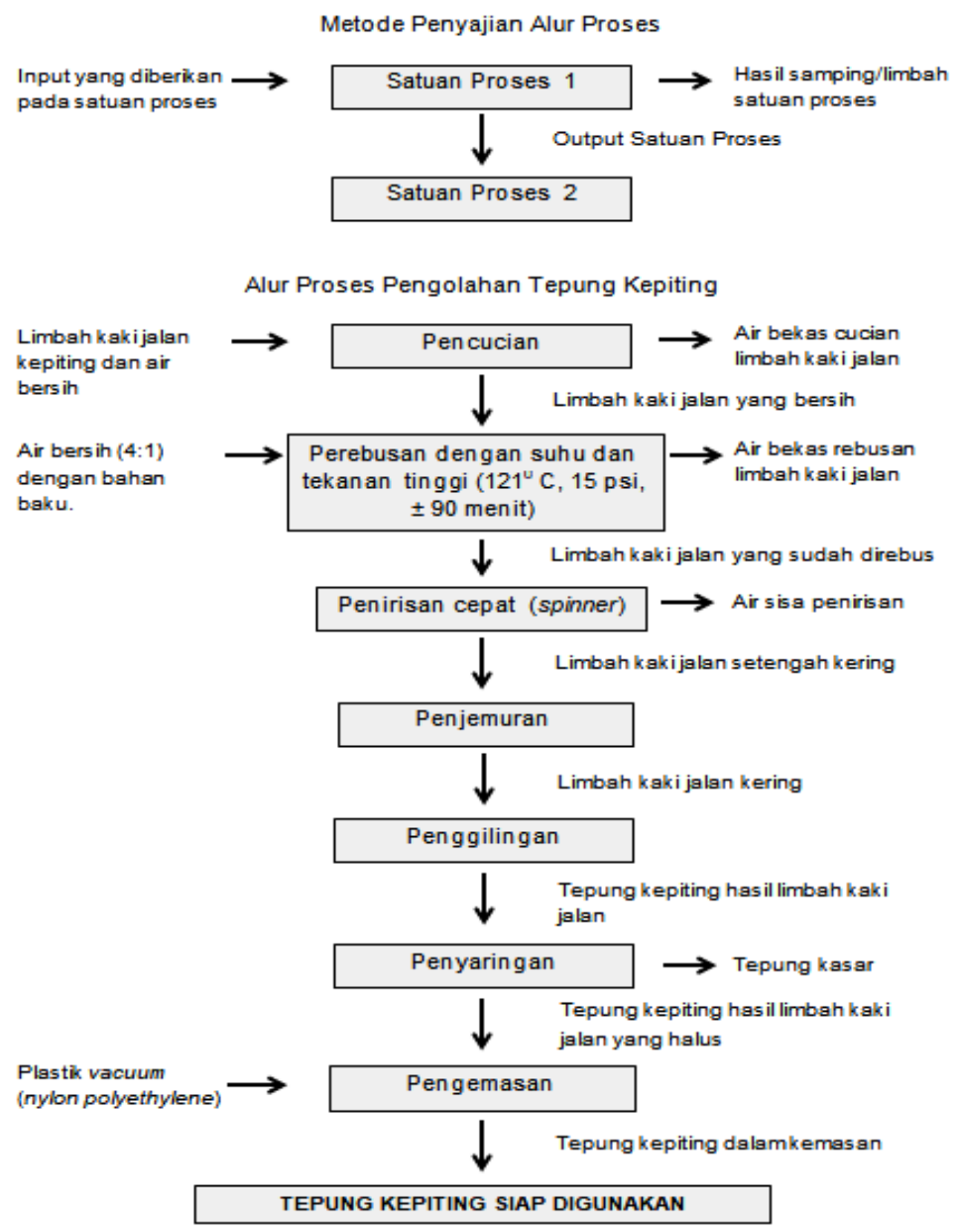

Gambar 1. Alur Proses Pengolahan Tepung Kepiting

\section{HASIL DAN PEMBAHASAN}

\section{Hasil}

Kapasitas bibit kepiting yang dibudidayakan oleh pembudidaya kepiting soka di Kota Banda Aceh dalam satu bulan rata rata berjumlah 1,5 ton. Bibit berasal dari wilayah Aceh Utara dan Aceh Timur dengan harga berkisar $R p 35.000$ - Rp 37.000. Size bibit kepiting yang diterima oleh pembudidaya berkisar antara $60-150$ g. Bibit kepiting didistribusikan menggunakan keranjang rotan selama \pm 8 jam menggunakan transportasi darat. Berdasarkan hasil pengamatan kondisi bibit mempunyai organ tubuh bibit lengkap, lincah , sehat dan sebagian besar berkelamin jantan. Berikut adalah informasi mengenai kapasitas bibit budidaya kepiting soka yang disajikan pada Tabel 1 
Teuku Muamar Indra Akbarsyah, dkk

Tabel 1. Kapasitas bibit budidaya kepiting soka di Kota Banda Aceh

\begin{tabular}{lccc}
\hline \multirow{2}{*}{ Data Bibit } & \multicolumn{3}{c}{ Pembudidaya Kepiting Soka } \\
\cline { 2 - 4 } & Pak Zulfan & Pak Ismiadi & Pak Martunus \\
\hline Ukuran (g) & $60-150$ & $60-150$ & $75-150$ \\
\hline Nama Supplier & Metro, Rahmat & Metro, Rahmat & Metro \\
\hline \multirow{2}{*}{ Asal } & $\begin{array}{c}\text { Aceh Utara, Aceh } \\
\text { Timur }\end{array}$ & Aceh Utara. Aceh Timur & Aceh Utara \\
\hline Kapasitas Bibit (kg) & 900 & 400 & 600 \\
\hline Harga (Rp) & 35.000 & 35.000 & 37.000 \\
\hline
\end{tabular}

Proses pemotongan kaki jalan pada budidaya kepiting soka di Kota Banda Aceh dilakukan dengan cara memotong ruas ketiga kaki jalan dengan tepat menggunakan gunting. Bagian ruas keempat akan jatuh dengan sendirinya hingga pangkal. Kepiting dipegang dengan cara khusus saat proses pemotongan kaki jalan berlangsung agar capit kepiting tidak menjepit jari. Kaki jalan yang terpotong selanjutnya ditampung dalam keranjang rotan oleh pembudidaya dan dibuang sebagai limbah. Berdasarkan hasil penelitian, limbah kaki jalan yang terbuang rata rata nya adalah $9,55 \%$ dari berat bahan baku setiap siklus budidaya. Berikut adalah informasi mengenai rata rata persentase rendemen kaki jalan kepiting per siklus budidaya yang disajikan pada Tabel 2.

Tabel 2. Rata rata persentase rendemen limbah kaki jalan per siklus budidaya

\begin{tabular}{lccc}
\hline Pengujian & $\begin{array}{c}\text { Berat Bahan Baku } \\
(\mathbf{k g})\end{array}$ & $\begin{array}{c}\text { Berat Limbah Kaki } \\
\text { Jalan }(\mathbf{k g})\end{array}$ & $\begin{array}{c}\text { Persentase Limbah } \\
\text { Kaki Jalan }(\%)\end{array}$ \\
\hline 1. & 100 & 9,20 & 9,20 \\
2. & 95 & 9,40 & 9,89 \\
3. & 100 & 9,43 & 9,43 \\
4. & 100 & 9,40 & 9,40 \\
5. & 48 & 4,74 & 9,88 \\
6. & 57 & 5,50 & 9,65 \\
7. & 100 & 9,00 & 9,00 \\
8. & 100 & 9,60 & 9,60 \\
9. & 95 & 9,51 & 10,01 \\
10. & 200 & 18,90 & 9,45 \\
Rata Rata & $\mathbf{8 9 , 5}$ & $\mathbf{9 , 4 7}$ & $\mathbf{9 , 5 5}$ \\
\hline
\end{tabular}


Proses pengolahan tepung kepiting telah kering dihaluskan dimulai dari tahapan pencucian menggunakan blender hingga limbah kaki jalan menggunakan air bersih dengan pengulangan sebanyak 3 kali sehingga memenuhi kriteria bahan baku pembuatan tepung kepiting. Bahan baku selanjutnya direbus dengan suhu $121^{\circ} \mathrm{C}$ dan tekanan 15 psi menggunakan panci presto selama \pm 90 menit dengan perbandingan bahan baku dan air rebusan 1:4. Bahan baku yang telah direbus, ditiriskan menggunakan spinner untuk mengurangi kadar air pada bahan, selanjutnya dijemur menggunakan para-para selama \pm 1 menjadi tepung, selanjutnya dilakukan proses penyaringan menggunakan ayakan untuk memisahkan partikel tepung yang kasar. Hasil akhir dari proses ini adalah tepung halus yang selanjutnya dianalisis secara sensori dan dikemas dalam plastik vacuum. Berdasarkan hasil penelitian, ratarata rendemen tepung kepiting hasil limbah kaki jalan adalah 27,2\%. Berikut adalah informasi mengenai rata-rata persentase rendemen produk tepung kepiting yang disajikan pada Tabel 3.

hari hingga kering. Bahan baku yang

Tabel 3. Rata rata persentase rendemen produk tepung kepiting

\begin{tabular}{cccc}
\hline Pengujian & $\begin{array}{c}\text { Berat Limbah Kaki } \\
\text { Jalan (kg) }\end{array}$ & $\begin{array}{c}\text { Berat Tepung Kepiting } \\
\text { (kg) }\end{array}$ & $\begin{array}{c}\text { Persentase Limbah } \\
\text { Kaki Jalan (\%) }\end{array}$ \\
\hline 1. & 1 & 0,274 & 27,4 \\
2. & 1 & 0,280 & 28,0 \\
3. & 1 & 0,262 & 26,3 \\
Rata Rata & & & $\mathbf{2 7 , 2 3}$ \\
\hline
\end{tabular}

Rata rata nilai uji sensori dari produk tepung kepiting yang dihasilkan adalah 8,05. Berdasarkan SNI 2715:2013 nilai sensori tepung kepiting yang dihasilkan termasuk dalam kategori grade A. Berikut adalah informasi mengenai rata rata nilai uji sensori produk tepung kepiting yang disajikan pada Tabel 4 
Tabel 4. Rata rata nilai uji sensori produk tepung kepiting

\begin{tabular}{ccccc}
\hline \multirow{2}{*}{ Panelis } & \multicolumn{4}{c}{ Parameter Uji Sensori (2715:2013) } \\
\cline { 2 - 5 } & Kenampakan & Bau & Ukuran Butiran & Benda Asing \\
\hline 1. & 7 & 7 & 7 & 9 \\
2. & 9 & 7 & 7 & 9 \\
3. & 7 & 7 & 7 & 9 \\
4. & 9 & 9 & 7 & 9 \\
5. & 7 & 7 & 9 & 9 \\
6. & 7 & 9 & 7 & 9 \\
7. & 9 & 7 & 9 & 9 \\
8. & 7 & 9 & 9 & 9 \\
9. & 7 & 7 & 7 & 9 \\
10. & 7 & 9 & 9 & $\mathbf{9}$ \\
Rata Rata & $\mathbf{7 , 6}$ & $\mathbf{7 , 8}$ & $\mathbf{7 , 8}$ & \\
\hline Total Rata Rata & \multicolumn{5}{c}{$\mathbf{8 , 0 5}$} & \\
\hline
\end{tabular}

Produk tepung kepiting disajikan dalam Gambar 2.
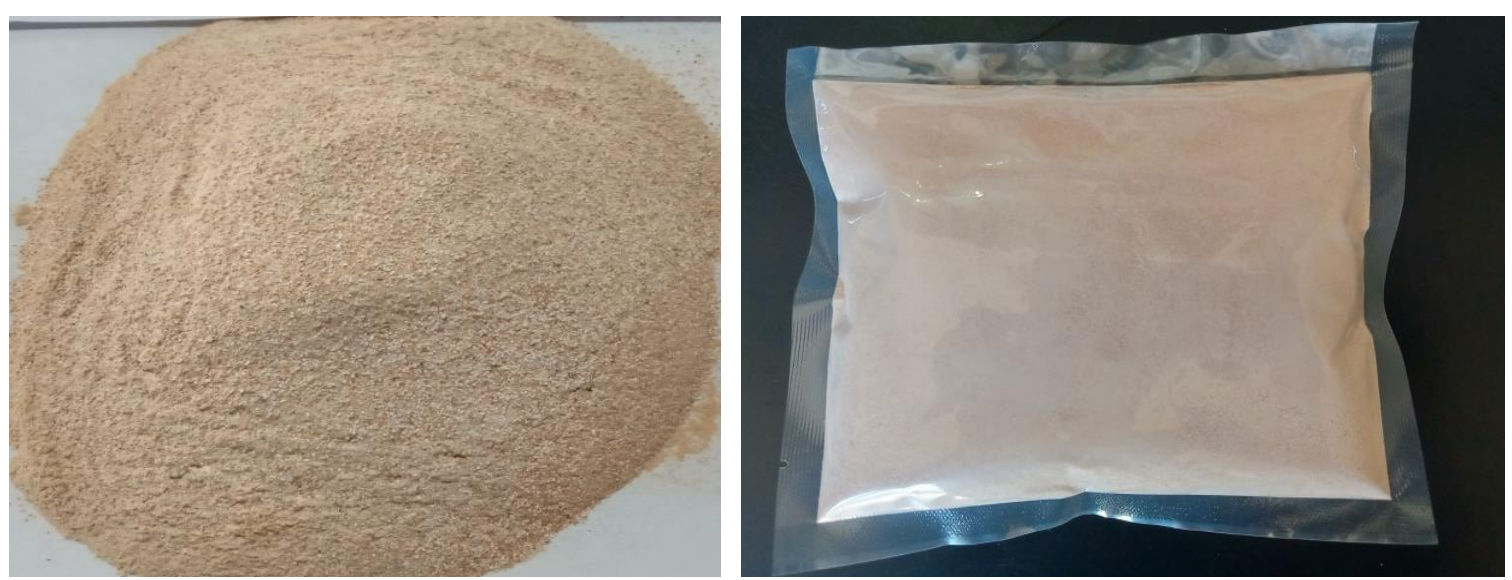

Gambar 2. Produk Tepung Kepiting

\section{Pembahasan}

Bibit yang diterima oleh pembudidaya kepiting soka di Kota Banda Aceh sesuai dengan standar. Ukuran bibit yang optimal adalah 60 - 150 g. Bibit kepiting dianggap sehat jika bergerak dengan aktif dan memiliki organ tubuh yang lengkap, sedangkan bibit kepiting yang tidak sehat dapat dilihat dari pergerakan yang lamban dan timbulnya warna kemerahan atau pudar pada cangkangnya. Jenis bibit yang digunakan adalah bibit jantan, hal ini dikarenakan jika menggunakan bibit betina dengan ukuran besar yaitu > $150 \mathrm{~g}$ sudah mulai bertelur dan sulit untuk moulting (Iromo et al., 2019). 
Bibit betina yang diterima oleh pembudidaya mempunyai size $<150$ g sehingga hal tersebut tidak berpengaruh terhadap proses moulting.

Teknik pemotongan kaki jalan merupakan salah satu kegiatan yang umum dilakukan oleh pembudidaya kepiting soka di Kota Banda Aceh. Pemotongan ini bertujuan untuk mempercepat proses panen, rata rata kepiting soka dipanen dalam waktu 3 minggu setelah proses penebaran bibit jika menggunakan teknik ini. Perlakuan pemotongan kaki jalan atau pemotongan kaki jalan dan kaki renang merupakan teknik mutilasi yang dilakukan pada kepiting untuk mempercepat proses moulting (Iromo et al., 2019). Pemotongan kaki jalan atau capit bisa dilakukan sebagian atau secara keseluruhan (Harianto E., 2015). Percepatan pertumbuhan dan penambahan bobot kepiting bakau yang dibudidayakan dapat dilakukan dengan teknik mutilasi kaki jalan sehingga mempercepat proses moulting. Selain kualitas air, teknik mutilasi juga memberi pengaruh terhadap kelangsungan hidup kepiting (Samidjan dan Rachmawati 2015)

Limbah kaki jalan merupakan hasil samping terbesar kedua yang terbuang saat proses budidaya kepiting soka setelah cangkang kepiting hasil moulting. Cangkang, kaki kepiting, kepala dan ekor pada umumnya mempunyai bobot $25-50 \%$ dari total bahan berat bahan baku (Trisnawati et al., 2013). Limbah yang dihasilkan dari budidaya kepiting soka mencapai 200 $\mathrm{kg} / \mathrm{bulan}$ dalam kondisi kering atau sebanyak 1500 kg/bulan dalam kondisi basah (Arthatiani et al., 2014). Hasil wawancara terhadap pembudidaya kepiting soka di Kota Banda Aceh, menunjukkan bahwa kapasitas bibit kepiting soka yang dibudidayakan $\pm 1,5$ ton/bulan Berdasarkan perhitungan rendemen limbah kaki jalan sebesar 9,55\% maka potensi pemanfaatan limbah kaki jalan adalah sebesar 143,25 kg.

Produksi tepung kepiting dari limbah kaki jalan membutuhkan waktu 1 hari yang dimulai dari tahapan persiapan bahan baku hingga pengemasan dan relatif lebih mudah digunakan sebagai bahan baku dibanding cangkang kepiting hasil moulting yang membutuhkan tahapan persiapan lebih lama. Kondisi limbah kaki jalan dapat diperoleh dalam keadaan segar sedangkan kondisi cangkang kepiting hasil moulting diperoleh dalam keadaan yang tidak bersih dan memiliki bau busuk.

Tahapan produksi tepung kepiting diawali dengan proses pencucian kaki jalan kepiting 
Pencucian berfungsi untuk membersihkan kaki jalan kepiting dari benda asing yang bisa mengontaminasi tepung yang dihasilkan. Pemanasan berfungsi untuk melunakkan kaki jalan kepiting sehingga mudah dihancurkan untuk menjadi tepung. Pemanasan cangkang rajungan pada proses pembuatan tepung rajungan dilakukan untuk memudahkan proses penepungan sehingga partikel yang dihasilkan mempunyai ukuran yang halus (Khasanah dan Hartati 2014).

Selain kondisi bahan baku, produksi sangat dipengaruhi dengan peralatan yang digunakan terutama alat penggilingan/penghalusan bahan baku menjadi tepung untuk memperoleh rendemen yang maksimal. Bahan baku dari cangkang kepiting hasil moulting rata rata memiliki rendemen sebesar $46,30 \%$ ketika menjadi produk kitosan (Sari \& Abdiani, 2015). Limbah kaki jalan merupakan hasil samping kedua terbesar yang terbuang saat proses budidaya setelah cangkang kepiting hasil moulting. Berdasarkan hasil rendemen yang diperoleh yaitu $27,23 \%$, jika dibandingkan dengan rendemen dari cangkang kepiting hasil moulting maka rendemen tepung kepiting yang dihasilkan cukup memadai. Kitosan yang dapat diproduksi menggunakan bahan baku tepung kepiting pada bidang medis digunakan sebagai bahan baku pembuat kapsul obat sesuai kriteria Farmakope Indonesia. Kapsul obat yang dihasilkan dapat larut dalam asam selama 3 menit 17 detik, hancur 13 menit 34 detik dan mempunyai kadar air sebesar $12,7 \%$ (Mashuni et al., 2021). Selain digunakan pada bidang farmasi dan pembuatan pakan, tepung kepiting digunakan sebagai fortifikasi bahan pangan untuk meningkatkan kandungan kalsium pada produk tertentu. Pada pembuatan produk dough pizza yang menggunakan tepung rajungan sebesar $10 \%$ menghasilkan produk yang disukai oleh konsumen yang dibuktikan oleh hasil uji sensori (warna, aroma, tekstur dan rasa) terhadap produk (Aprilia, 2020)

Grade mutu tepung ikan berdasarkan uji sensori dengan nilai A adalah minimal 7 dengan rentang penilaian 1-9 (SNI 2715:2013). Berdasarkan hasil uji sensori nilai yang diperoleh adalah 8,05 , maka tepung kepiting yang dihasilkan dari limbah kaki jalan secara uji sensori masuk dalam mutu yang paling baik (Grade A). Hasil scoresheet menunjukkan nilai terendah adalah pada parameter kenampakan, hal ini disebabkan warna tepung kepiting cenderung agak kecokelatan. Sedangkan nilai tertinggi terdapat pada parameter benda asing, hal ini 
disebabkan ketiadaan benda asing dalam produk karena bahan baku yang dalam keadaan segar dan tidak tercampur dengan benda lain, serta proses produksi yang dilakukan dengan cepat dan cermat. Tepung rajungan sebagai bahan perisa yang baik dapat diperoleh dengan perlakuan pengeringan pada suhu $60^{\circ}$ C. Hasil uji organoleptik menunjukkan bahwa, tepung yang dihasilkan memiliki tekstur dan warna yang baik, serta rasa dan roma yang netral (Mulyadi et al., 2013)

\section{KESIMPULAN}

Hasil penelitian ini menunjukkan beberapa identifikasi yang penting terhadap produksi tepung kepiting dari hasil samping budidaya kepiting soka berupa limbah kaki jalan. Limbah kaki jalan hasil mutilasi mempunyai potensi sebagai bahan baku produk tepung kepiting sebesar 143,25 kg/bulan. Rendemen tepung kepiting sebesar $27,23 \%$, maka potensi produk tepung kepiting yang dapat dihasilkan perbulan adalah $39 \mathrm{~kg}$. Hasil uji sensori menunjukkan kualitas tepung kepiting yang dihasilkan telah memenuhi SNI 2715:2013 yaitu 8,05. Beberapa hasil tersebut menunjukkan indikator bahwa potensi pemanfaatan limbah kaki jalan dari hasil samping budidaya kepiting soka untuk dijadikan tepung kepiting dapat dilakukan.

\section{SARAN}

Saran dari hasil penelitian ini adalah perlunya penelitian lanjutan mengenai uji pasar, kandungan nutrisi, serta efektivitas dan efisiensi penggunaan produk tepung kepiting yang dihasilkan sehingga bisa dimanfaatkan oleh pembudidaya dan konsumen secara optimal.

\section{PERSANTUNAN}

Ucapan terima kasih ditujukan kepada Pak Zulfan, Pak Ismiadi dan Pak Martunus selaku pembudidaya kepiting soka di Kota Banda Aceh yang telah memfasilitasi kegiatan penelitian ini.

\section{DAFTAR PUSTAKA}

A.Z, A., F.A, I., Ng, H. ., \& Praveena, S. . (2014). An Experimental and Modelling Study of Selected Heavy Metals Removal from Aqueous Solution Using Scylla serrata as Biosorbent. Pertanika Journal of Science and Technology, 22(2), 553-566.

Aprilia, P. (2020). Pemanfaatan Cangkang Rajungan Pada Pembuatan Pizza Dengan Topping Daging Rajungan Sambal Balacan (crabby pizza) Sebagai One Dish Meal Kaya 
Teuku Muamar Indra Akbarsyah, dkk

Protein dan Kalsium. Prosiding

Pendidikan Teknik Boga

Busana Fakultas Teknik

Universitas Negeri Yogyakarta, 15(1), 1-6.

Arthatiani, F. Y., Luhur, E. S.,

Zulham, A., \& Haryadi, J.

(2014). Peluang Optimalisasi

Pengembangan Budidaya

Kepiting Soka di Wilayah

Kimbis Cakradonya Kota

Banda Aceh. Jurnal Kebijakan

Sosial Ekonomi Kelautan Dan

Perikanan,

https://doi.org/10.15578/jksekp

.$v 4 \mathrm{i} 2.601$

Badan Standarisasi Nasional.

(2013). Tepung Ikan - Bahan

Baku Pakan. SNI 2715:2013.

Badan Standarisasi Nasional. Jakarta

Boey, P. L., Maniam, G. P., \& Hamid, S. A. (2009). Utilization of waste crab shell (Scylla serrata) as a catalyst in palm olein transesterification. Journal of Oleo Science, 58(10), 499-502. https://doi.org/10.5650/jos.58.4 99

Fajri, F., Thaib, A., \& Handayani, L. (2019). Penambahan mineral kalsium dari cangkang kepiting bakau Scylla serrata pada pakan terhadap pertumbuhan dan kelangsungan hidup udang galah Macrobrachium rosenbergii. Jurnal IImu-IImu
Perairan, Pesisir Dan

Perikanan, 8(3), 185-192. https://doi.org/10.13170/depik.

8.3.12090

Hamka, M. I., Caronge, M. W., \& Fadilah,

$\mathrm{R}$. (2020).

Pemanfaatan

Cangkang

Rajungan (Portunus pelagicus.

sp) dan Eceng Gondok

Sebagai Sumber Kalsium

Pada Pakan Ayam. Jurnal

Pendidikan

Teknologi

Pertanian, 6(1), 79-86.

Handayani, L., Zuhrayani, R., \& Thaib, A. (2019). Karakteristik Kimia Tepung Cangkang Kepiting. Jurnal Abulyatama Semdi Unaya, 112-116.

Harianto E. (2015). Kinerja Produksi Kepiting Bakau Scylla serrata Cangkang Lunak pada Metode Pemotongan Capit dan Kaki Jalan, Popey, dan Alami. Jurnal Ilmiah Universitas Batanghari Jambi, 15(1), 1521.

Haryati, E., Dahlan, K., Togibasa, O., \& Dahlan, K. (2019). Protein and Minerals Analyses of Mangrove Crab Shells (Scylla serrata) from Merauke as a Foundation on Bioceramic Components. Journal of Physics: Conference Series, 1204(1).

https://doi.org/10.1088/1742-

6596/1204/1/012031 
Iromo, H., Amien, M., \& Suliadi. (2019). Studi Budidaya Kepiting Soka (Soft Crab) di Tambak Tradisional Pulau

Tarakan Kalimantan Utara Aquaculture. Jurnal Borneo Saintek, 2(April), 68-74.

Khairiah, Wardoyo, S. E., \& Wahid, P. (2012). Pengaruh Mutilasi dan Ablasi Terhadap Molting Kepiting Bakau ( Scylla Serrata ) Sebagai Kepiting Lunak. Jurnal Sains Natural Universitas Nusa Bangsa, 2, 81-91.

Khasanah, S., \& Hartati, I. (2014).

Fortifikasi Tepung Terigu Oleh

Tepung Cangkang Rajungan (Portunus pelagicus) Pada Pembuatan Mie Basah. Prosiding Seminar Nasional Sains Dan Teknologi 5 2014, 1(1), 81-85.

Luhur, E. S., \& Zulham, A. (2016).

Potensi Pemanfaatan Limbah

Perikanan di Banda Aceh.

Buletin IImiah "MARINA" Sosial

Ekonomi Kalautan Dan

Perikanan, 2(1), 37-44.

Mashuni, M., Natsir, M., Mia, W., \& Handayani, F. (2021). Pemanfaatan Kitosan dari Cangkang Kepiting Bakau ( Scylla serrata ) dengan. ALCHEMY Jurnal Penelitian Kimia, 17(1), 74-82. https://doi.org/10.20961/alche

my.17.1.42038.74-82

Mulyadi, A. F., Maligan, J. M., \& Hermansyah, R. (2013). Karakterisitik Organoleptik Serbuk Perisa Alami Dari Cangkang Rajungan (Portunus pelagicus): Kajian Konsentrasi Dekstrin dan Suhu Pengeringan. Jurnal Teknologi Pertanian, 14(3), 183-192.

Samidjan, I., \& Rachmawati, D. (2015). Rekayasa Budidaya Kepiting Bakau Melalui Pemotongan Kaki Jalan Dalam Upaya Peningkatan Produksi Kepiting Soka. Jurnal Online Universitas Pekalongan, 103121.

Sari, P. D., \& Abdiani, I. M. (2015). Pemafaatan Kulit Udang dan Cangkang Kepiting Sebagai Bahan Baku Kitosan. Jurnal Harpodon Borneo, 8(2), 142147.

Trisnawati, E., Andesti, D., \& Saleh, A. (2013). Pembuatan Kitosan dari Limbah Cangkang Kepiting sebagai Bahan Pengawet Buah Duku dengan Variasi Lama Pengawetan. Jurnal Teknik Kimia, 19(2), 17-26.

Yanuar, V. (2013). Tepung cangkang rajungan (portunus pelagicus) sebagai sumber kalsium. Juristek, 2(1), 185194. 